\title{
Antimicrobial Proteins and Peptides in Early Life: Ontogeny and Translational Opportunities
}

\author{
Anna J. Battersby ${ }^{1,2 *}$, Jasmeet Khara ${ }^{1,3}$, Victoria J. Wright ${ }^{1}$, Ofer Levy ${ }^{4,5}$ and \\ Beate Kampmann ${ }^{1,2}$
}

${ }^{1}$ Academic Paediatrics, Imperial College London, London, UK, ${ }^{2}$ Medical Research Council (MRC) Unit, Vaccines and Immunity Theme, Fajara, Gambia, ${ }^{3}$ Department of Pharmacy, National University of Singapore, Singapore, ${ }^{4}$ Precision Vaccines Program, Department of Medicine, Division of Infectious Diseases, Boston Children's Hospital, Boston, MA, USA, ${ }^{5}$ Harvard Medical School, Boston, MA, USA

\section{OPEN ACCESS}

Edited by:

Kieran G. Meade,

Teagasc - The Irish Agriculture and Food Development Authority, Ireland

Reviewed by: Miriam Wittmann, University of Leeds, UK

Gill Diamond,

University of Florida, USA

*Correspondence:

Anna J. Battersby

a.battersby@imperial.ac.uk

Specialty section: This article was submitted to Immunotherapies and Vaccines,

a section of the journal

Frontiers in Immunology

Received: 30 May 2016

Accepted: 29 July 2016

Published: 18 August 2016

Citation:

Battersby AJ, Khara J, Wright VJ, Levy O and Kampmann B (2016)

Antimicrobial Proteins and

Peptides in Early Life: Ontogeny and

Translational Opportunities.

Front. Immunol. 7:309.

doi: 10.3389/fimmu.2016.00309
While developing adaptive immune responses, young infants are especially vulnerable to serious infections, including sepsis, meningitis, and pneumonia. Antimicrobial proteins and peptides (APPs) are key effectors that function as broad-spectrum anti-infectives. This review seeks to summarize the clinically relevant functional qualities of APPs and the increasing clinical trial evidence for their use to combat serious infections in infancy. Levels of APPs are relatively low in early life, especially in infants born preterm or with low birth weight (LBW). There are several rationales for the potential clinical utility of APPs in the prevention and treatment of infections in infants: (a) APPs may be most helpful in those with reduced levels; (b) during sepsis microbial products signal via pattern recognition receptors causing potentially harmful inflammation that APPs may counteract; and (c) in the era of antibiotic resistance, development of new anti-infective strategies is essential. Evidence supports the potential clinical utility of exogenous APPs to reduce infection-related morbidity in infancy. Further studies should characterize the ontogeny of antimicrobial activity in mucosal and systemic compartments, and examine the efficacy of exogenous-APP formulations to inform translational development of APPs for infant groups.

Keywords: antimicrobial peptides, protein, peptide, infant, newborn, infection, innate, immunity

\section{INTRODUCTION}

During early life, the immune system of the newborn (first 28 days of life) and young infant (up to 3 months of age) undergoes remarkable functional change. Historically, the newborn immune system was thought to be an immature version of the adult. However, contemporary evidence suggests that neonatal responses are not simply "immature" but wholly unique, reflecting the distinct immunological needs of fetal versus newborn life (1). Antenatally, the fetus experiences a normally sterile environment until delivery, when the newborn infant is rapidly colonized and challenged with a broad array of microbes (2).

The challenge of immune adaption to this rapid environmental change from immune seclusion to immune challenge may contribute to the propensity of neonates to succumb to overwhelming infection (3). Unique newborn innate and adaptive immunity, reflecting the constraints and needs of the perinatal transition, may also contribute to this susceptibility. Distinct aspects include 
Th2-polarized responses of monocyte and dendritic cells via pattern recognition receptors (PRRs), $\mathrm{T}$ cell hyporesponsiveness to many stimuli (4) and a limited assortment of infant B-cells capable of producing high-affinity antibodies (5). These distinct features of newborn immunity may help prevent overwhelming, and potentially tissue-damaging pro-inflammatory responses and/or potential cross-reactive auto-immune responses to newly encountered microbes. During this immunological transitional period, certain "bridging" mechanisms help provide immune protection for the newborn. This includes "passive immunity" from the transplacental transfer of maternal antibodies to the fetus during pregnancy and postnatal transfer to the newborn primarily through breastfeeding. However, the neonate remains inadequately protected from infection, with over one-third of deaths during the neonatal period directly attributable to perinatal infections, including sepsis, meningitis, pneumonia, and diarrheal disease $(6,7)$.

In the absence of developed adaptive immunity, infants may particularly depend upon innate immune mechanisms to combat infections. Indeed, primary immune deficiencies, such as MyD88 and IRAK4 defects in the toll-like receptor (TLR) pathways, present in early life, and survival past the neonatal phase is associated with much lower risk of infection $(8,9)$. Antimicrobial proteins and peptides (APPs) are a key effector arm of innate immunity that function as broad-spectrum anti-infectives against a wide array of Gram-negative and Gram-positive bacteria, mycobacteria, fungi, and enveloped viruses (10-12). In this review, we discuss the capacity of the newborn and infant to express and deploy APPs; how this may affect early life responses to infection; and how exogenous APPs or agents that induce APP expression may have clinical utility in this age group (Figure 1), based on systematically collected data using the methods described in Tables 1 and 2 .

Relative to older infants and adults, newborns (particularly those born preterm) demonstrate lower levels of circulating APPs and reduced cellular release of APPs at sites of infection. This relative deficiency of APPs may contribute to the high risk of invasive infections in early life $(13,14)$. Factors, such as age, including gestational age at birth, may influence the physiological levels of APPs in infancy. Table 3 depicts APP levels in preterm and term neonates according to anatomical site. Newborns are at increased risk of infection by microbes including fungi (15), Gramnegative bacteria, such as Escherichia coli (E. coli) and Klebsiella pneumoniae (K. pneumoniae), and Gram-positive bacteria, such as Staphylococcus aureus (S. aureus), Streptococcus pneumoniae (S. pneumoniae), and Group B Streptococcus (GBS) (15).

\section{WHAT ARE ANTIMICROBIAL PEPTIDES AND PROTEINS?}

Antimicrobial proteins and peptides are fascinating cationic molecules that are released primarily by neutrophils, monocytes, and macrophages by secretion or during degranulation. APPs are also produced within the skin and at mucosal surfaces by epithelial cells in the respiratory, gastrointestinal, and urinary tract and thus, are present within bodily fluids, including saliva, tears, nasal secretion, gastric juice, sweat, semen, airway surface liquid, and breast milk (35). Clinically important APPs in early life include defensins, cathelicidins, protegrins, bactericidal/ permeability-increasing protein (BPI), S100 proteins (e.g., calprotectin), lactoferrin (LF), lysozyme, and RNAses (e.g., 4, 5, and 7) (13).

Defensins are disulfide-rich cationic peptides expressed in plants, insects, fungi, and mammals, including humans (36). Humans express $\alpha$-defensins (human neutrophil peptides HNP-1, HNP-2, HNP-3, HNP-4, and human defensins HD-5 and -6) and human $\beta$-defensins (HBDs including HBD-1, HBD-2, and HBD-3 $(28,37))$. Cathelicidins are multifunctional bactericidal peptides with $\mathrm{N}$-terminal fragments bearing a structural similarity to the protease inhibitor cathelin (38), and include human cathelicidin (LL-37), bovine Indolicidin and Ranalexin (39). Protegrins are porcine APPs, structurally similar to cathelins, and have served as templates for development of congeners for therapeutic use in humans (40). BPI is a 456 residue LPS-neutralizing anti-infective protein stored within primary granules of human polymorphic neutrophils (PMNs), and has been developed as a synthetic therapeutic $\left(\mathrm{rBPI}_{21}\right)(41,42)$. Calprotectin is a predominantly neutrophil-derived metal-chelating protein of the S100 protein family (43), which is gaining recognition as a potential diagnostic marker for necrotizing enterocolitis (NEC). LF is a neutrophil and mammalian-milk derived protein based on one polypeptide chain that contains around 700 amino acids and forms two homologous globular domains (N-and C-lobes) $(44,45)$.

Antimicrobial proteins and peptides can be constitutively expressed, and/or inducible in response to proinflammatory stimuli. Cathelicidins and HNPs 1-4 are both constitutively expressed and inducible. Lysozyme, LF, HD5-6, and HBD1 are only constitutively expressed, and HBDs 2-4 are only detectable in response to stimuli (46). APPs facilitate effective pathogen clearance by both direct antimicrobial action and immunomodulatory functions $(11,35,47)$, inducing angiogenesis, promoting wound healing (10), inhibiting LPS-induced proinflammatory responses $(10,48)$, modulating adaptive cellular immune responses (13, 49), mediating immune cell ontogeny in the lung and gut, and acting as chemoattractants for other immune cells. Chemokines and cytokines regulate the release of APPs but can also display direct antimicrobial activity themselves: indeed, up to two-thirds of human chemokines have been shown to have some direct antibacterial action (46).

Antimicrobial proteins and peptides target invading bacteria via initial electrostatic contact at the anionic bacterial surface. The specific mode of action differs between APP families but permeabilization of target cytoplasmic membranes is a common crucial step in APP-mediated antimicrobial activity and cytotoxicity (47). The concept of extracellular entrapment of bacteria, and the contribution of APPs to this process, has advanced in recent years, both in relation to antibacterial activity at epithelial surfaces and within the bloodstream. Yost et al. describe neutrophil extracellular traps (NETs), which are lattices of extracellular DNA, chromatin, and APPs that mediate extracellular killing of bacteria (50). A similar process occurs at the intestinal mucosal surface whereby defensins form nanonets to trap bacteria and combat invasion across the intestinal barrier into deeper tissues (51). 


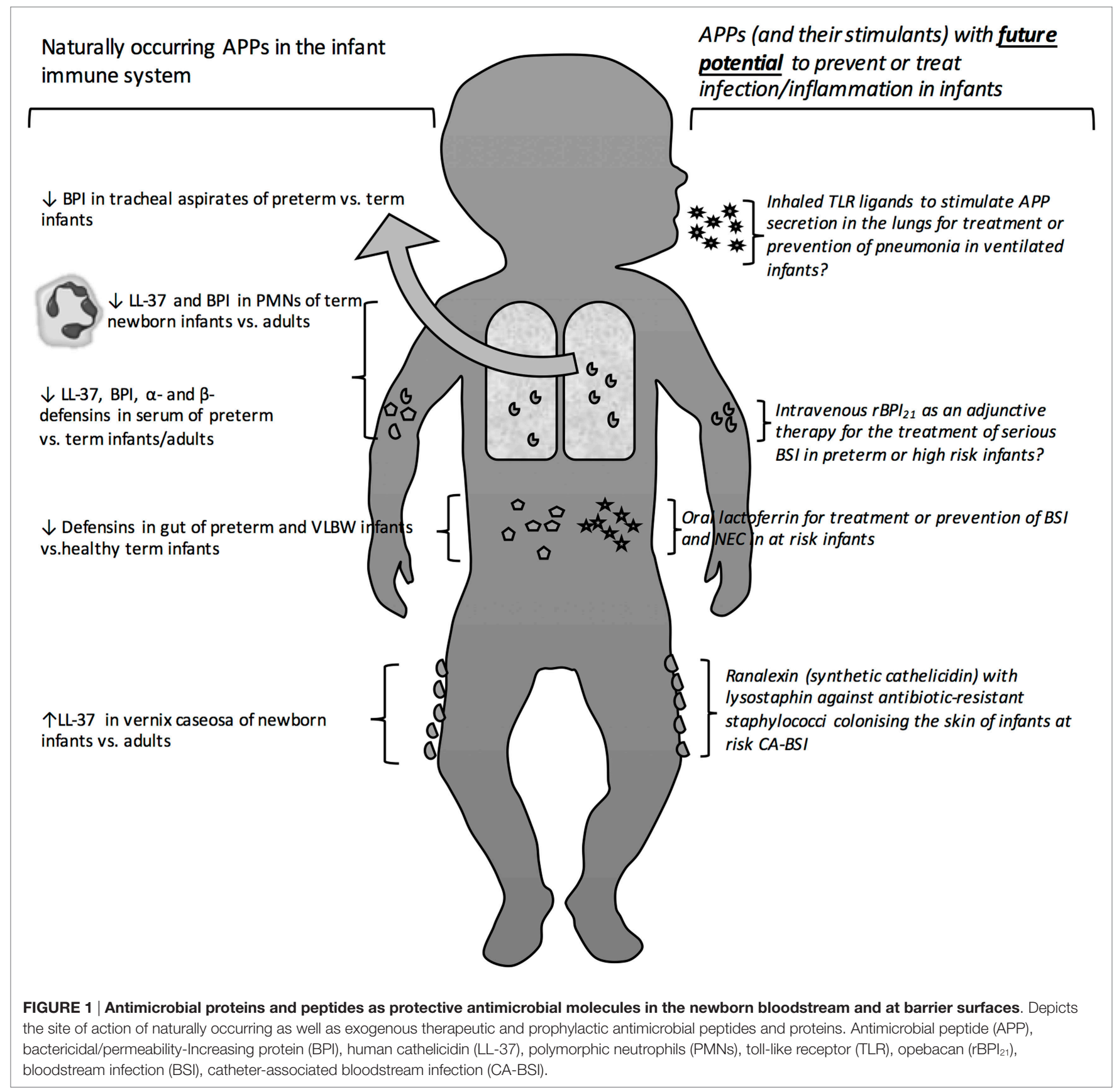

APPs have potential as stand alone therapeutics or as adjunctive agents, to reduce either length of antibiotic treatment and/ or inflammation induced by killed microbes/microbial products (52). Important APPs that have undergone clinical trials include $\mathrm{rBPI}_{21}$; Pexiganan, an analog of Magainin (MSI-78) (53); Iseganan (IB-367), a protegrin mimetic; Omiganan pentahydrochloride (CLS001), an Indolicidin analog; Brilacidin, a defensin mimetic; LTX-109, a shortlactoferricin-basedpeptide(54), andTalactoferrin, an analog of $\operatorname{LF}(55,56)$. The terms analog and mimetic are used, respectively, to describe synthetic compounds with closely similar molecular structure versus those with a closely similar functional capacity to that of an endogenous APP (see Table 4).

\section{APPS AND THE SKIN: AT THE FRONTLINE OF IMMUNE DEFENSES}

Many APPs exert their main effects at the frontlines of the body's immune defenses - the skin and mucosal surfaces. The skin acts as both a physical barrier and a chemical barrier to potential pathogenic organisms hosting an array of APPs including LL-37, LF, a- and b-defensins (see Table 3). HBD-2 is particularly effective against both Gram-negative and Grampositive bacteria, such as E. coli and S. aureus, respectively (40). Amphibian skin has proven to be a promising source of new APPs (57), which can be chemically synthesized for human 
TABLE 1 | Literature search strategy.

\begin{tabular}{|c|c|c|c|c|}
\hline Antimicrobial peptide & AND/OR & Infant & AND/OR & Sepsis \\
\hline $\begin{array}{l}\text { Antimicrobial protein } \\
\text { Lactoferrin } \\
\text { Cathelicidin } \\
\text { LL-37 } \\
\text { BPI } \\
\text { Cathelin } \\
\text { HNP-1 } \\
\text { HNP-2 } \\
\text { HNP-3 } \\
\text { HBD-1 } \\
\text { HBD-2 } \\
\text { HBD-3 } \\
\text { Protegrin }\end{array}$ & & $\begin{array}{l}\text { Neonat* }^{\star} \\
\text { Early life } \\
\text { Newborn } \\
\text { Birth }\end{array}$ & & $\begin{array}{l}\text { Infection } \\
\text { Pneumonia } \\
\text { Diarrhea } \\
\text { Necrotizing } \\
\text { enterocolitis } \\
\text { Bacteremia } \\
\text { BSI } \\
\text { Meningitis } \\
\text { Preterm } \\
\text { Prematur* } \\
\text { Low birth weight } \\
\text { Skin } \\
\text { Intestin* } \\
\text { Breast milk } \\
\text { Amnion* } \\
\text { Blood } \\
\text { Lung } \\
\text { Immun* }\end{array}$ \\
\hline
\end{tabular}

A search for articles was performed using a "systematic review" based method: searching through the Pubmed database using a detailed search strategy with keywords and MeSH terms as listed above. Rapid assessment of the literature to identify the most relevant articles through a rapid screen of titles and abstracts by 1 reviewer. Article selection removed duplicates and the remainder were then screened based on inclusion criteria below.

Where appropriate * was placed at the end of a group of letters ("trunk" of the word) to retrieve all possible variations.

TABLE 2 | Inclusion criteria for referenced studies.

\section{Inclusion criteria}

Language English

Populations

$$
\text { All }
$$

Articles that

Antimicrobial protein and peptide (APP) expression and include

research on

secretion during the first year of life within the blood, mucosal surfaces, and bodily fluids, including preterm, low birth weight, and infected human infants. Clinical trials of APPs as therapeutics that show promise for use in the treatment or prevention of neonatal infections and inflammatory conditions. Where relevant reference animal studies that support clinical studies or hypotheses relating to human infants

Description of the studies included in the structured review: topics covered and reasons for their inclusion.

use. For example, Pexiganan (an analog of magainin - isolated from the skin of the African clawed frog) shows promise for use in the treatment of localized skin infections in humans (53). Staphylococcus epidermidis (S. epidermidis) is commonly found on the skin, and is responsible for clinically significant infection in preterm and low birth weight (LBW) infants (58). LL-37 significantly inhibits growth of $S$. epidermidis isolated from the skin of newborn infants (59), and the reduced levels of LL-37 in preterms (6) may contribute to their susceptibility to S. epidermidis infection. In fact, in newborn infants, the lesions of a commonly encountered harmless rash only seen in the neonatal period, termed as "erythema toxicum," are densely filled with LL-37 expressing neutrophils and eosinophils. While the exact trigger for the erythema toxicum rash remains unclear, it appears that activation of innate immune cells to express APPs occurs and, thus, colonization of the skin with microbial flora may initiate this process (22).

\section{APPS IN THE LUNGS AND DURING PNEUMONIA}

Airborne organisms can gain entry to the human host through the airways, but the lung tissue is well protected from invasion by epithelial lining fluid that is rich in APPs (60); including LL-37, defensins, and lysozyme (32). Resident mucosal immune cells (e.g. alveolar macrophages), epithelial cells, and systemic immune cells (recruited to the lung epithelium at times of microbial challenge) all contribute to the secretion of APPs into epithelial lining fluid (33). During an episode of pneumonia, increased levels of APPs are detectable in bronchoalveolar lavage (BAL) fluid (21). It is clear that HBD-2 is the predominant defensin in neonatal lung, and whether defensin levels are lower in preterm or term infants is yet to be established (30). However, there appear to be reduced levels of BPI in the lungs of preterm infants compared to term infants, which may contribute to the higher risk of pneumonia in this age group; with lower lung APPs, preterm infants may be unable to clear pathogenic organisms effectively $(30,33,61)$.

\section{APPS IN THE INTESTINE IN HEALTH AND DISEASE}

The human intestine harbors a broad array of micro-organisms (the intestinal microbiome), which are increasingly understood to interact dynamically with the host immune system potentially leading to long-term effects on health. APPs are believed to significantly alter environmental microbiota and influence expression of pattern-recognition receptors at the intestinal epithelial surface (62). Indeed, mouse models have helped describe the homeostatic role of $\alpha$-defensins in regulating the makeup of the commensal microbiota in the neonatal intestine (63). However, while hosting beneficial bacteria, the intestinal mucosa must also protect itself from dangerous invasive organisms: Paneth cells contribute to this protection by secreting defensins and other APPs into the intestinal fluid. The various mechanisms by which gut defensins in particular are able to protect the intestinal mucosa from microbial invasion continue to be elucidated. Recent work published in Science describes eloquently how HD-6 released from Paneth cells undergoes a complex self-assembly into nanonets and fibrils at the ostia of crypts, allowing highly effective entrapment of bacteria and preventing damage to stem cells at the base of crypts (51).

There is a paucity of literature describing APP function in the healthy human newborn and infant gut, but some inferences can be made from studies of animals, and of human fetal tissue. Perhaps contrary to what we might expect, a recent study indicates that specific APP levels are increased in the mouse intestine during the neonatal period. The intestinal intraepithelial cell (IEC) mRNA expression levels of the mouse cathelicidin-related antimicrobial peptide (mCRAMP), the murine intestinal homolog of human LL-37, is highly expressed in healthy term neonatal epithelium and becomes less abundant during the postnatal period as IEC proliferation and differentiation occurs (64). Indeed, mCRAMP expression has previously also been shown to be increased in embryonic and neonatal mouse skin, when compared with adult 
TABLE 3 | Differential levels of antimicrobial peptides and proteins (APPs) according to age and anatomical site.

\begin{tabular}{|c|c|c|c|c|}
\hline $\begin{array}{l}\text { Family/ } \\
\text { peptide }\end{array}$ & Site & $\begin{array}{l}\text { Sample } \\
\text { type }\end{array}$ & Age groups & APP levels \\
\hline \multirow[t]{5}{*}{$\begin{array}{l}\text { Cathelicidin: } \\
\text { LL37 }\end{array}$} & Blood & $\begin{array}{l}\text { Whole } \\
\text { blood }\end{array}$ & $\begin{array}{l}\text { Neonates and } \\
\text { adults }\end{array}$ & $\begin{array}{l}\text { Lower levels in preterm than term neonates and mothers (enzyme-linked immunosorbent - ELISA) } \\
\text { (16). Lower levels in neonatal than in adult neutrophils (flow cytometry), but no difference in plasma } \\
\text { levels (ELISA) (17) }\end{array}$ \\
\hline & Breast & Breast milk & Mothers & $\begin{array}{l}\text { Present in expressed breast milk (EBM) of mothers of term and preterm neonates (reverse- } \\
\text { transcriptase PCR (RT-PCR) and ELISA) and in EBM-derived cells (direct immunoprecipitation and } \\
\text { western blot) }(18,19)\end{array}$ \\
\hline & Gut & $\begin{array}{l}\text { Feces/ } \\
\text { meconium }\end{array}$ & Term neonates & Distinct inter-individual variation in feces and meconium (western blot) (20) \\
\hline & Lungs & $\begin{array}{l}\text { Tracheal } \\
\text { aspirates }\end{array}$ & $\begin{array}{l}\text { Preterm/term } \\
\text { neonates }\end{array}$ & $\begin{array}{l}\text { Detected in bronchoalveolar lavage fluid (BALF) of mechanically ventilated neonates (antigen capture } \\
\text { dot-blot assay), concentration did not vary with gestational age (21) }\end{array}$ \\
\hline & Skin & $\begin{array}{l}\text { Skin } \\
\text { biopsies/ } \\
\text { vernix } \\
\text { caseosa }\end{array}$ & $\begin{array}{l}\text { Term neonates } \\
\text { and adults }\end{array}$ & $\begin{array}{l}\text { Site-specific expression profile, with expression in human skin biopsies of newborns } \\
\text { (immunohistochemistry) (22), higher levels within neonatal foreskin compared to adults (immune } \\
\text { staining) (23), and dense expression in vernix of newborns (enhanced chemiluminescence western blot } \\
\text { detection system (22) and reverse-phase chromatography-dot blot/western blot analyses) (24) }\end{array}$ \\
\hline \multirow[t]{4}{*}{$\begin{array}{l}\alpha \text {-defensins: } \\
\text { HNP-1, }-2 \text {, and } \\
-3 \text {, and HD-5 }\end{array}$} & Blood & $\begin{array}{l}\text { Whole } \\
\text { blood }\end{array}$ & $\begin{array}{l}\text { Preterm/term } \\
\text { neonates and } \\
\text { mothers }\end{array}$ & $\begin{array}{l}\text { Significantly lower HNP-1, }-2 \text {, and }-3 \text { levels in preterm and term neonates compared to mothers } \\
\text { (ELISA) (16). Significantly higher HNP-1 and }-3 \text { levels in preterm infants delivered to mothers with } \\
\text { amniotic infection, compared to normal deliveries (ELISA). Correlation between gestation and HNP } \\
\text { levels in preterm infants (25) }\end{array}$ \\
\hline & Breast & Breast milk & Mothers & $\begin{array}{l}\text { Significantly higher HD5 levels in breast milk from mothers at day } 7 \text { than at day } 21 \text {, and no association } \\
\text { between HD5 levels and risk of sepsis (19) }\end{array}$ \\
\hline & Gut & $\begin{array}{l}\text { Feces/ } \\
\text { meconium }\end{array}$ & Term neonates & $\begin{array}{l}\text { HNP-1 and -2 in meconium and neonatal feces (ELISA). HNP-3 in meconium (Matrix-assisted laser } \\
\text { desorption/ionization-mass spectrometry (MALDI-MS)) (20). HD5 in meconium and feces of neonates } \\
\text { (weak cationic exchange chromatography and reversed-phase chromatography/MALDI-MS) (20) }\end{array}$ \\
\hline & Skin & $\begin{array}{l}\text { Vernix } \\
\text { caseosa }\end{array}$ & Term neonates & $\begin{array}{l}\text { The main antimicrobial components in vernix (HPLC, dot blot analysis, mass spectrometry (24), and } \\
\text { western analysis (26)) }\end{array}$ \\
\hline \multirow{5}{*}{$\begin{array}{l}\beta \text {-defensins: } \\
\text { HBD-1 and } \\
\text { HBD-2 }\end{array}$} & Blood & $\begin{array}{l}\text { Whole } \\
\text { blood }\end{array}$ & $\begin{array}{l}\text { Mother-infant } \\
\text { pairs }\end{array}$ & $\begin{array}{l}\text { Significantly lower HBD-2 (ELISA) in serum of preterm compared to term infants. Low levels of HBD-2 } \\
\text { may be associated with increased risk of late onset sepsis (LOS) (27) }\end{array}$ \\
\hline & Breast & Breast milk & Mothers & $\begin{array}{l}\text { HBD-1 and HBD-2 levels (ELISA) significantly higher at day } 7 \text { than day } 21 \text {, and displayed antimicrobial } \\
\text { activity against neonatal pathogens. No difference between levels fed to infants with and without LOS } \\
\text { (19) }\end{array}$ \\
\hline & Gut & $\begin{array}{l}\text { Feces/ } \\
\text { meconium }\end{array}$ & $\begin{array}{l}\text { Preterm/term } \\
\text { neonates }\end{array}$ & $\begin{array}{l}\text { Similar levels of HBD-2 in preterm and term infants (ELISA), both of which are significantly higher than } \\
\text { in children or adults (28). Significant lower levels in feces compared to meconium (ELISA) (29) }\end{array}$ \\
\hline & Lungs & $\begin{array}{l}\text { Tracheal } \\
\text { aspirates/ } \\
\text { lung tissue }\end{array}$ & $\begin{array}{l}\text { Preterm/term } \\
\text { neonates }\end{array}$ & $\begin{array}{l}\text { Present in tracheal aspirates (TA) (antigen capture dot-blot assay) with similar levels in preterm and } \\
\text { term infants ( } 21) . \mathrm{HBD}-2 \text { is the predominant defensin in neonatal lung, and levels (RT-PCR) appear to } \\
\text { be developmentally regulated (30) }\end{array}$ \\
\hline & Skin & $\begin{array}{l}\text { Skin } \\
\text { biopsies }\end{array}$ & $\begin{array}{l}\text { Term neonates/ } \\
\text { adults }\end{array}$ & $\begin{array}{l}\mathrm{HBD}-1 \text { is constitutively expressed in human skin (22) and HBD-2 levels comparable between perinatal } \\
\text { and adult skin (immunohistochemistry) (23) }\end{array}$ \\
\hline \multirow[t]{2}{*}{$\mathrm{BPI}$} & Blood & $\begin{array}{l}\text { Whole } \\
\text { blood }\end{array}$ & $\begin{array}{l}\text { Preterm/term } \\
\text { neonates, and } \\
\text { adults }\end{array}$ & $\begin{array}{l}\text { Three- to fourfold lower cellular content of BPI in neonatal compared to adult neutrophils (western } \\
\text { blot) (31). Lower plasma levels of BPI in preterm infants compared to mothers (ELISA) (16), and lower } \\
\text { ability to release BPI from neutrophils in preterm than term infants and adults (ELISA) (32). Higher levels } \\
\text { in infants delivered prematurely due to maternal amniotic infection (ELISA). No association between } \\
\text { gestational age and BPI levels (25) }\end{array}$ \\
\hline & Lungs & $\begin{array}{l}\text { Tracheal } \\
\text { aspirates }\end{array}$ & $\begin{array}{l}\text { Preterm/term } \\
\text { neonates }\end{array}$ & $\begin{array}{l}\text { Higher levels in term than preterm infants and significant increase in first postnatal week, as detected } \\
\text { in acid extracts of neonatal TA polymorphic neutrophils (PMNs) (ELISA) (33) }\end{array}$ \\
\hline \multirow[t]{2}{*}{ Lactoferrin } & Maternal & Breast milk & Mothers & $\begin{array}{l}\text { Most abundant APP present within breast milk of mothers of preterm infants (ELISA) with significantly } \\
\text { higher levels at day } 7 \text { than day } 21 \text { (19) }\end{array}$ \\
\hline & Skin & $\begin{array}{l}\text { Skin } \\
\text { surface/ } \\
\text { vernix } \\
\text { caseosa }\end{array}$ & $\begin{array}{l}\text { Term neonates } \\
\text { and adults }\end{array}$ & $\begin{array}{l}\text { Enriched on neonatal skin surface compared to adults (34), and identified in vernix of full-term infants } \\
\text { (western analysis) (26) }\end{array}$ \\
\hline
\end{tabular}

Summary of the results of published human studies assessing APP levels in preterm infants, term infants, their mothers, and other adults. Study results are reported in the context of the anatomical site and sample type assessed, the methods used, and the age of the study participants.

skin (23). Further research is required to explore whether this specific developmental phenomenon exists in the skin and intestinal mucosae of human infants.

Conversely, studies of human fetal intestinal tissue support the premise that APP levels are relatively diminished in early life: reduced mRNA expression levels of HD-5 and HD- 6 have been reported within terminal ileal tissue at 24 -week gestation compared to full-term infants and adults (65). Indeed, data suggest that low levels of defensins in preterm infants are associated with increased incidence of intestinal pathology, in particular the devastating illness, Necrotizing enterocollitis (NEC) (66). NEC etiology is incompletely understood but an interplay exists between host factors [prematurity, very low birth weight (VLBW)], the intestinal microbiota and enteral feeds. APPs 
TABLE 4 | Important synthetic antimicrobial proteins and peptides according to the endogenous compounds from which they are derived.

\begin{tabular}{|c|c|c|}
\hline Origin & Endogenous compounds & $\begin{array}{l}\text { Exogenous synthetic } \\
\text { compounds }\end{array}$ \\
\hline Bovine & $\begin{array}{l}\text { - Indolicidin } \\
\text { - Bovine Lactoferrin }(B L F)^{b}\end{array}$ & $\begin{array}{l}\text { - Omiganan } \\
\text { pentahydrochloride } \\
\text { (CLS001) } \\
\text { - LTX-109 }\end{array}$ \\
\hline Porcine & $\begin{array}{l}\text { - } \text { Protegrin } \\
\text { - }(\beta \text {-defensin } 2(p B D-2)\end{array}$ & $\begin{array}{l}\text { - Iseganan (IB-367) } \\
\text { - } \text { pBD-2 }^{\mathrm{a}}\end{array}$ \\
\hline Amphibian & $\begin{array}{l}\text { - Ranalexin } \\
\text { - Magainin }\end{array}$ & $\begin{array}{l}\text { - Polymixin } \\
\text { - Pexiganan (MSI-78) }\end{array}$ \\
\hline Human & $\begin{array}{l}\text { - Human defensins } \\
\text { - Cathelicidin } \\
\text { - Bactericidal/permeability- } \\
\text { increasing protein (BPI) } \\
\text { - Lactoferrin (LF) }\end{array}$ & $\begin{array}{l}\text { - } \text { Brilacidin } \\
\text { - } \mathrm{N} / \mathrm{A} \\
\text { - } \mathrm{rBPI}_{21} \\
\text { - } \text { Talactoferrin and LTX-109 }\end{array}$ \\
\hline
\end{tabular}

${ }^{a}$ Denotes promising compounds currently in pre-clinical experimental stages, all other synthetic forms are in clinical trial stages.

${ }^{b}$ Denotes compounds in the endogenous form that have undergone human clinical trial.

potentially contribute, as animal models have shown that depletion of Paneth cells of $\alpha$-defensins followed by enteric infection results in a clinical picture akin to human neonatal NEC (67).

Ileal tissue from infants with NEC show elevated defensin levels compared to age-matched controls, likely indicating that at some stage in the pathogenesis of the disease, Paneth cells are induced to increase production of defensins (65). Higher HBD-2 concentrations appear to have a protective effect once NEC pathology is established, in that they have been associated with more moderate courses of the disease. Indeed, in severe NEC, low HBD-2 expression is accompanied by low TLR4/ MD2 expression, suggesting an inadequate response to luminal bacteria, possibly predisposing to the development of NEC (29). Calprotectin levels have been extensively investigated in neonatal stool samples, as a potential screening marker for the detection of NEC. A recent systematic review of the literature confirmed fecal calprotectin levels are elevated in NEC, but whether this is robust enough to act as a diagnostic test early in the disease, and what relevance the levels have to disease progression and severity remains unclear (43).

An important mode by which the infant intestinal mucosal surface is furnished with APPs, is through ingestion of maternal breast milk. APPs may contribute to the ability of breast milk to protect the newborn from inflammatory and infectious diseases. Several APPs have been identified in breast milk, including LF (68), lysozyme (69), LL-37 (18), $\alpha$-, and $\beta$-defensins $(19,70)$. Importantly, LF is abundant at concentrations sufficient to inhibit bacterial growth $(19,70)$. Given its multi-functional immunomodulatory, anti-inflammatory, and antimicrobial properties, LF supplementation in VLBW has been increasingly studied for the prophylactic treatment of bloodstream infection (BSI) and NEC (71). Evidence supports the notion that combinations of components working in synergy contribute to the antimicrobial activity of breast milk, as exemplified by the concomitant action of LF with bovine RNase 5 (angiogenin-1), RNase 4, and angiogenin-2 (72). A strategy of mimicking the synergistic nature of breast milk derived APPs and associated molecules has potential for future therapeutics.

\section{APPs IN THE BLOOD AND BLOODSTREAM INFECTION}

APPs consistently circulate in the bloodstream, they are transported freely within the plasma, and provide an ongoing low-level non-specific immune defense against potential invasive pathogens. Cellular expression and secretion of some APPs, including defensins (73), LL-37 (74), and BPI can be mediated by TLRs (6). In infants with BSI with bacterial etiology, plasma BPI concentrations are higher than those in healthy infants, which indicates that BPI transcription and/or cellular secretion is upregulated during infection $(41,75)$. Additionally, healthy uninfected neonates born to mothers who have suffered from an amniotic infection demonstrate higher levels of LF, BPI, HNP-1, HNP-2, and HNP-3 in the cord plasma (25). Maternal plasma LL-37 levels appear to be the most important predictor of infant plasma LL-37 levels, and although the source of these APPs in cord blood is not known, it is possible that these higher levels may not be a reflection of the functional status of the infant's own immune system, but an example of maternally derived transplacentally transferred immune protection (76).

However, generally, intracellular levels of APPs are lower in neonates than in later life: LL-37 and BPI levels are reduced in neonatal whole blood and neutrophils when compared with adults $(17,31,32,77)$, and BPI deficiency of neutrophils in neonates is associated with reduced bacterial-killing capacity (41). It is yet to be established whether an infant's intrinsic intracellular or plasma levels of APPs influence an individual's risk of developing a BSI, or indeed the clinical outcome following BSI. Measuring serum, plasma or even resting-state intracellular levels of APPs have obvious limitations in understanding the importance of differences between neonates and adults. Indeed, more relevant perhaps is identification of functional impairments of the innate immune response in neonates, such as defective NET formation resulting in impaired bacterial killing in vitro (78). Further characterization of the functional capacities of peripheral blood neutrophils in term and preterm infants will undoubtedly yield insights into understanding neonatal BSI and developing strategies for its prevention and cure.

\section{THE PREMATURE INFANT: A SPECIAL CASE}

Premature birth significantly increases susceptibility to serious infections, including BSI, meningitis, and pneumonia $(79,80)$. APP levels are generally lower in preterm than in full-term infants, including within the bloodstream (16) (both in the circulating plasma and intracellularly within immune cells), at epithelial surfaces and within bodily fluids and feces $(6,29,30)$ (Table 3$)$. This relative deficiency in APPs may contribute to the preterm infant's increased risk for invasive bacterial infection (13). Importantly, higher levels of APPs (including HBD-1, HBD-2, and LL-37) are seen in the blood and body fluids of those with acute infections, 
such as BSI (81) and respiratory infection (21). Increased levels of APPs in cord blood of infants born to mothers with a history of BSI or chorioamnionitis (25) is important in the context of premature infants, as preterm delivery is often triggered by amniotic infection that may, therefore, act as a significant confounder when assessing for effect of gestational age on APP levels. Studies not taking a history of chorioamnionitis into account should, therefore, be interpreted with caution $(21,28)$.

\section{CLINICAL APPLICATION OF APPS: PROMISING EVIDENCE FROM CLINICAL TRIALS IN ADULTS?}

While the number of APPs undergoing pre-clinical development has been increasing, the majority of clinical trials have focused on topical formulations with few trials in the pediatric population (Table 5). Several lead compounds, including Pexiganan, Iseganan, and Omiganan have failed to achieve late stage development due to their failure to meet primary trial endpoints, or disappointingly insurmountable regulatory hurdles (56). Currently, Dipexium Pharmaceutical's Locilex (Pexiganan cream 0.8\%) is the only APP undergoing a phase III clinical trial, for the treatment of mild wound infections (NCT01594762). Cellceutix Corporation recently completed phase II trials of Brilacidin in acute bacterial skin infections (NCT02052388) and have begun preclinical studies in otitis media and ocular infections. Cutanea Life Sciences has identified new indications (including skin infections) for Omiganan (CLS001), which was previously not approved for urinary tract infections (NCT02456480). Lytix Biopharma has completed phase II trials of LTX-109 in impetigo (a problematic condition primarily affecting young children). Several pharmaceutical companies are developing APPs for systemic administration, such as Agennix AG who are pursuing the development of oral Talactoferrin in severe sepsis (NCT00630656). Results from their phase II randomized controlled trial (RCT) showed a significant reduction in all-cause mortality at 28 days and 6 months in the treatment group (82) yet, the recent follow on phase II/III RCT (OASIS trial) was terminated prematurely over concerns of safety and efficacy (55). Interestingly the APP that has undergone most advanced clinical testing using the intravenous (IV) route is $\mathrm{rBPI}_{21}$, which was assessed for its efficacy in meningococcemia in children (42). Other AMPs, such as LF 1-11 (hLF1-11), are undergoing safety and tolerability testing for delivery via the IV route in healthy volunteers (83).

\section{CLINICAL APPLICATIONS OF APPs IN INFANTS}

Evidence supports the use of recombinant congeners of APPs to improve circulating levels and potentially reduce the incidence of, and/or improve outcomes from bacterial infection in infants. APPs have been used to prevent infections and aberrant inflammation in high-risk infants, such as premature and LBW infants. A large, multicentre, double-blind, RCT comparing LF supplementation alone or in combination with probiotics demonstrated a significant reduction in late onset sepsis (LOS) in VLBW infants in both treatment groups as compared to placebo controls (84). Secondary analysis of data from the same RCT showed significant reductions in incidence rates of invasive fungal infection in both treatment groups as compared to placebo controls (85). A third LF study demonstrated that the same treatment interventions significantly diminished incidence of NEC in VLBW infants (86). These findings were reiterated in a smaller RCT which found that LF-treated infants experienced fewer primary but also secondary episodes of sepsis as compared to placebo (87). A recent Peruvian study also reported that infants receiving LF were less likely to develop sepsis than placebo controls (88). Taken together, these findings highlight the feasibility of supplemental LF, either alone or in combination with probiotics, as a promising approach to protect VBLW infants from neonatal infections.

Invasive meningococcal disease is a rare but devastating disease, associated with high morbidity and mortality in the young. Promising preclinical data supported the antibacterial and anti-endotoxin properties $\mathrm{rBPI}_{21}$, while phase I/II trials demonstrated the safety of $\mathrm{rBPI}_{21}$ in adults and suggested beneficial effect on inflammatory biomarkers in children with severe meningococcal sepsis, thus prompting a phase III RCT for this indication (89). The study, whose youngest participant was $\sim 2$ weeks old, suggested that $\mathrm{rBPI}_{21}$ conferred benefit with respect to mortality and morbidity. By intention to treat analysis, mortality was lower in the rBPI group, though not significantly. A sub-group analysis of those who survived to complete the first infusion of rBPI or placebo demonstrated nearly a $50 \%$ reduction in mortality in the $\mathrm{rPP}_{21}$ group. Although the study was underpowered to detect significant changes in mortality by intention to treat analysis, $\mathrm{rBPI}_{21}$-treated study participants had a substantial reduction in severe limb amputations, shorter ICU stay, and better return to baseline function. These results suggest the potential utility of $\mathrm{rBPI}_{21}$ in reducing meningococcalassociated complications and, if approved such that it could be given even sooner in the sepsis cascade, would likely confer even greater benefit. Notably, when administered to total body irradiated mice, $\mathrm{rBPI}_{21}$ demonstrated benefit in conjunction with conventional fluoroquinolone antibiotic, including more rapid recovery of the hematopoietic compartment and improved survival suggesting that it may be a useful adjunct in those deficient in BPI due to chemoradiotherapy (90). These results raise the possibility to extend the beneficial effects of $\mathrm{rBPI}_{21}$ to other populations that are relatively deficient in functional BPI activity, including the preterm infant group.

\section{FUTURE POTENTIAL OF APPS IN DISEASES OF INFANCY}

Circulating and intracellular levels of APPs are relatively low in early life, especially in those born preterm or with LBW, potentially contributing to susceptibility to infection. There are several rationales for the potential clinical utility of APPs in the prevention and treatment of infections in infants: (a) APPs may be most helpful in those with reduced levels; (b) during sepsis microbial products signal via PRRs causing potentially harmful inflammation which APPs may counteract; and (c) in the era of 
TABLE 5 | Antimicrobial peptides and proteins evaluated in clinical trials for the treatment of infections in children.

\begin{tabular}{|c|c|c|c|c|c|c|c|}
\hline Peptide & $\begin{array}{l}\text { Clinical } \\
\text { application }\end{array}$ & $\begin{array}{l}\text { Treatment } \\
\text { arms }(n)^{\mathrm{a}}\end{array}$ & Phase $^{b}$ & Status & Company & Outcome & $\begin{array}{c}\text { Reference/ } \\
\text { Reg no. }\end{array}$ \\
\hline $\begin{array}{l}\text { Opebacan } \\
\left(\mathrm{rBPI}_{21}\right) \text { : } \\
\text { recombinant } \\
21-\mathrm{kDa} \text { modified } \\
\text { fragment } \\
\text { of human } \\
\text { bactericidal/ } \\
\text { permeability- } \\
\text { increasing } \\
\text { protein (BPI) }\end{array}$ & $\begin{array}{l}\text { Severe } \\
\text { meningococcal } \\
\text { sepsis }\end{array}$ & $\begin{array}{l}\mathrm{rBPl}_{21}(190) \\
\text { Placebo (203) }\end{array}$ & III & Complete & Xoma & $\begin{array}{l}\text { The trial was underpowered to detect } \\
\text { significant differences in mortality. } \\
\text { However, patients receiving } \mathrm{rBPI}_{21} \text { had } \\
\text { a trend toward improved outcome in } \\
\text { all primary outcome variables, and the } \\
\text { study authors concluded that } \mathrm{rBPI}_{21} \text { is } \\
\text { beneficial in decreasing complications } \\
\text { of meningococcal disease }\end{array}$ & Levin (42) \\
\hline \multirow[t]{8}{*}{$\begin{array}{l}\text { Bovine } \\
\text { lactoferrin (BLF): } \\
80 \text { kDa naturally } \\
\text { occurring } \\
\text { multifunctional } \\
\text { glycoprotein of } \\
\text { the transferrin } \\
\text { family }\end{array}$} & $\begin{array}{l}\text { Late-onset } \\
\text { sepsis } \\
\text { Invasive fungal } \\
\text { infections }\end{array}$ & $\begin{array}{l}\text { BLF (153) } \\
\text { BLF plus LGG } \\
\text { (151) } \\
\text { Placebo (168) }\end{array}$ & NS & Complete & $\begin{array}{l}\text { Saint Anna Foundation } \\
\text { and Dicofarm }\end{array}$ & $\begin{array}{l}\text { Compared with placebo, BLF } \\
\text { supplementation alone or in } \\
\text { combination with LGG (Lactobacillus } \\
\text { rhamnosus GG) reduced the } \\
\text { incidence of a first episode of late- } \\
\text { onset sepsis in VLBW neonates (84). } \\
\text { Prophylactic oral administration of } \\
\text { BLF also reduces the incidence of } \\
\text { invasive fungal infection in preterm } \\
\text { VLBW neonates }\end{array}$ & $\begin{array}{c}\text { ISRCTN53107700; } \\
\text { Manzoni } \\
(84,85,86)\end{array}$ \\
\hline & $\begin{array}{l}\text { Necrotizing } \\
\text { enterocolitis }\end{array}$ & $\begin{array}{l}\text { BLF (247) } \\
\text { BLF plus LGG } \\
\text { (238) } \\
\text { Placebo (258) }\end{array}$ & NS & Complete & & $\begin{array}{l}\text { Compared with placebo, BLF } \\
\text { supplementation alone or in } \\
\text { combination with LGG reduced the } \\
\text { incidence of } \geq \text { stage } 2 \text { NEC and of } \\
\text { death-and/or } \geq \text { stage } 2 \text { NEC in VLBW } \\
\text { neonates (86) }\end{array}$ & \\
\hline & $\begin{array}{l}\text { Late-onset } \\
\text { sepsis } \\
\text { Necrotizing } \\
\text { enterocolitis }\end{array}$ & $\begin{array}{l}\text { BLF (22) } \\
\text { Placebo (25) }\end{array}$ & NS & Complete & Ankara University & $\begin{array}{l}\text { Fewer sepsis episodes were } \\
\text { observed in LF-treated infants with } \\
\text { none developing NEC, without } \\
\text { statistical significance (87) }\end{array}$ & $\begin{array}{l}\text { NCT01287507; } \\
\text { Akin } 2014 \text { (87) }\end{array}$ \\
\hline & $\begin{array}{l}\text { Late-onset } \\
\text { sepsis }\end{array}$ & $\begin{array}{l}\text { BLF (95) } \\
\text { Placebo (95) }\end{array}$ & $\|$ & Complete & $\begin{array}{l}\text { Universidad Peruana } \\
\text { Cayetano Heredia }\end{array}$ & $\begin{array}{l}\text { Overall sepsis occurred less } \\
\text { frequently in the LF group than in the } \\
\text { control group. Although the primary } \\
\text { outcome did not reach statistical } \\
\text { significance (88) }\end{array}$ & NCT01264536 (88) \\
\hline & & $\begin{array}{l}\text { BLF } \\
\text { Placebo }\end{array}$ & III & Ongoing & & & NCT01525316 \\
\hline & $\begin{array}{l}\text { Healthcare- } \\
\text { associated } \\
\text { infections } \\
\text { Necrotizing } \\
\text { enterocolitis }\end{array}$ & $\begin{array}{l}\text { BLF } \\
\text { Placebo }\end{array}$ & NS & Complete & $\begin{array}{l}\text { Research Center of } \\
\text { Sainte Justine, } \\
\text { Canada }\end{array}$ & Results awaited & ISRCTN66482337 \\
\hline & $\begin{array}{l}\text { Late-onset } \\
\text { sepsis }\end{array}$ & $\begin{array}{l}\text { BLF } \\
\text { Placebo }\end{array}$ & III & Ongoing & $\begin{array}{l}\text { National Health and } \\
\text { Medical Research } \\
\text { Council, Australia }\end{array}$ & Results awaited & $\begin{array}{c}\text { ACTRN12611000 } \\
247976\end{array}$ \\
\hline & $\begin{array}{l}\text { Late-onset } \\
\text { sepsis }\end{array}$ & $\begin{array}{l}\text { BLF } \\
\text { Placebo }\end{array}$ & III & Ongoing & $\begin{array}{l}\text { The National Institute } \\
\text { for Health Research, } \\
\text { UK }\end{array}$ & Results awaited & ISRCTN88261002 \\
\hline
\end{tabular}

${ }^{a} B L F$, bovine lactoferrin; LGG, probiotic Lactobacillus rhamnosus GG; GOS; galacto-oligosaccharides. Sample size (n) is absent for trials either in progress or completed but unpublished. "NS, "not stated."

${ }^{\circ}$ Reference or registration numbers are obtained from http://clinicaltrials.gov, http://www.isrctn.com, and http://www.anzctr.org.au.

antibiotic resistance, development of new anti-infective strategies is essential.

Clinical trials of oral LF and IV $\mathrm{rBPI}_{21}$ have suggested significant clinical benefit lending support to the hypothesis that APPs, either induced endogenously or as exogenously administered congeners, may help prevent and treat infections in highly susceptible infants in early life: particularly premature or VLBW infants. Future strategies should identify and develop APPs with potential for prevention and treatment of the most devastating diseases: BSI, pneumonia, CNS infection, diarrheal 
disease, and NEC. There are a number of strategies that have as yet made little progress in clinical trials: such as inhaled TLR ligands that can stimulate production of APPs at the lung surface. The company Pulmotech have developed "PUL-042"; a novel combination of two synthetic TLR agonists (Pam2 and ODN) (91) that will begin Phase 1b/2a clinical studies this year in immunosuppressed adults at high risk of developing pneumonia. PUL-042 or similar compounds could be considered for use to reduce pneumonia in at risk infants, such as ventilated premature or VLBW infants.

\section{APPS IN THE ERA OF ANTIBIOTIC RESISTANCE}

In the era of antibiotic resistance individual APPs, combinations of APPs, or agents that induce their expression (e.g. TLR agonists), may serve as novel alternatives to antibiotics. It has been proposed that bacterial resistance to APPs is much less likely to evolve than to conventional antibiotics, owing to their broad, non-specific antibacterial mechanism of action (92). The in vivo response to infection involves the action of multiple endogenous APPs and, thus, a combination therapy of multiple synthetic APPs may be a better therapeutic option than an individual agent.

As long-term survival rates of preterm and VLBW infants in neonatal intensive care units (NICUs) increase, so does morbidity associated with catheter-associated blood-stream infections (CA-BSIs). Neonates are at particular risk of exposure to antibiotic resistant bacterial BSIs: specifically, from, methicillin-resistant Staphylococcus aureus (MRSA), vancomycin-resistant enterococci (VRE), and extended spectrum beta-lactamase producing Gram-negative bacteria (ESBL) (93). New strategies are needed to eradicate antibiotic-resistant bacterial strains, including those colonizing or infecting the skin and mucosal surfaces, before the organisms gain entry to the bloodstream. Experimental data are emerging on the potential of APPs as single or synergistic agents to existing therapies in this regard.

In the case of staphylococcal-resistant organisms, a recent study using a skin explant model to assess the efficacy of Ranalexin with an endopeptidase (Lysostaphin) found that the combination was able to rapidly and specifically kill resistant staphylococcal species without adversely affecting normal skin microflora (94). Additionally, a group from Singapore have designed four hybrid peptides (based on Indolicidin and Ranalexin), which display strong antibacterial activity against MRSA in vitro (95), and another in vitro study identified Indolicidin (and a number of other APPs) alone and in combination with antibiotics, as potential candidates for future therapeutics against MRSA biofilms (96). The underlying mechanisms explaining these synergistic effects against MRSA remain to be completely elucidated. An in vitro and in vivo study of Nafcillin (an anti-staphylococcal $\beta$-lactam) identified that it enhances killing of MRSA by increasing the binding of LL-37 to the MRSA membrane.

Infection with penicillin-resistant strains of S. pneumonia can be a serious therapeutic challenge in the young infant. Recently, a Malaysian research group designed a novel hybrid peptide "DM3" that has shown synergistic therapeutic efficacy in combination with penicillin in a mouse model of systemic infection with a strain of penicillin-resistant $S$. pneumoniae (97). Design and testing of APPs to ensure maximal efficacy while limiting toxicity is of paramount importance for the vulnerable infant age group.

\section{A BROAD-BASED APPROACH TO FUTURE RESEARCH}

Newborn infants and in particular those born prematurely are highly susceptible to invasive and often overwhelming sepsis. Data from the World Health Organization suggest that worldwide every year 1.1 million neonates die from infection (3). Evidence is growing for the potential of APPs to be useful in the reduction of morbidity and mortality from infection in infancy in both resource-rich and resource-poor countries. Further research is needed, including in vitro and in vivo studies characterizing the ontogeny of global cellular and soluble antimicrobial and antiinfective (e.g. endotoxin-neutralizing) activity within systemic compartments and at epithelial surfaces. These basal surveys will then need to be systematically compared in relation to induced and exogenous-APP supplemented fluids to inform translational development of APPs in high-risk populations, including newborn and infant groups.

\section{AUTHOR CONTRIBUTIONS}

$\mathrm{AB}, \mathrm{OL}$, and $\mathrm{BK}$ contributed to the conception of the review article. $\mathrm{AB}, \mathrm{JK}$, and $\mathrm{VW}$ undertook the literature review and identified key papers for inclusion. $\mathrm{AB}$ and $\mathrm{JK}$ drafted the initial article, and $\mathrm{OL}, \mathrm{VW}$, and $\mathrm{BK}$ contributed to all revisions and subsequent drafts. All authors have given final approval for the version submitted for publication.

\section{ACKNOWLEDGMENTS}

The authors would like to acknowledge the contributions of Jankey Ya Jagne and Hadi Sallah to the early drafts of the manuscript. All authors have read and acknowledge the journal's authorship agreement.

\section{FUNDING}

$\mathrm{AB}$ is supported by a Wellcome Trust clinical research training fellowship. BK is supported by funding from the Medical Research Council (MC_UP_A900/1122) and the NIHR based at Imperial College Healthcare NHS Trust and Imperial College London. JK is supported by the President's Graduate Fellowship from the National University of Singapore. VW is supported by Great Ormond Street Hospital Charity (v1401). OL laboratory is supported by a Boston Children's Hospital Department of Medicine award to the Precision Vaccines Program and by NIH Infant Immunity grant (1R01AI100135-01) and its Administrative Supplements. 


\section{REFERENCES}

1. Marchant A, Kollmann TR. Understanding the ontogeny of the immune system to promote immune-mediated health for life. Front Immunol (2015) 6:77. doi:10.3389/fimmu.2015.00077

2. Battersby AJ, Gibbons DL. The gut mucosal immune system in the neonatal period. Pediatr Allergy Immunol (2013) 24(5):414-21. doi:10.1111/pai.12079

3. WHO. Levels and Trends in Childhood Mortality. New York, USA: WHO, United Nations Children's Fund (2013).

4. Fehervari Z. Neonatal non-responsiveness. Nat Immunol (2015) 16:906. doi:10.1038/ni.3261

5. Dowling DJ, Levy O. Ontogeny of early life immunity. Trends Immunol (2014) 35:299-310. doi:10.1016/j.it.2014.04.007

6. Strunk T, Currie A, Richmond P, Simmer K, Burgner D. Innate immunity in human newborn infants: prematurity means more than immaturity. J Matern Fetal Neonatal Med (2011) 24:25-31. doi:10.3109/14767058.2010.482605

7. Wardlaw T, You D, Hug L, Amouzou A, Newby H. UNICEF report: enormous progress in child survival but greater focus on newborns urgently needed. Reprod Health (2014) 11:82. doi:10.1186/1742-4755-11-82

8. Bernuth von H, Picard C, Puel A, Casanova J-L. Experimental and natural infections in MyD88- and IRAK-4-deficient mice and humans. Eur J Immunol (2012) 42:3126-35. doi:10.1002/eji.201242683

9. Picard C, Casanova J-L, Puel A. Infectious diseases in patients with IRAK-4, MyD88, NEMO, or IкB $\alpha$ deficiency. Clin Microbiol Rev (2011) 24:490-7. doi:10.1128/CMR.00001-11

10. Zanetti M. Cathelicidins, multifunctional peptides of the innate immunity. J Leukoc Biol (2004) 75:39-48. doi:10.1189/jlb.0403147

11. Levy O. Antimicrobial proteins and peptides: anti-infective molecules of mammalian leukocytes. J Leukoc Biol (2004) 76:909-25. doi:10.1189/jlb.0604320

12. Frew L, Stock SJ. Antimicrobial peptides and pregnancy. Reproduction (2011) 141:725-35. doi:10.1530/REP-10-0537

13. Kai-Larsen Y, Gudmundsson GH, Agerberth B. A review of the innate immune defence of the human foetus and newborn, with the emphasis on antimicrobial peptides. Acta Paediatr (2014) 103:1000-8. doi:10.1111/apa.12700

14. Levy O. Antimicrobial proteins and peptides of blood: templates for novel antimicrobial agents. Blood (2000) 96:2664-72.

15. Pana Z-D, Kougia V, Roilides E. Therapeutic strategies for invasive fungal infections in neonatal and pediatric patients: an update. Expert Opin Pharmacother (2015) 16:693-710. doi:10.1517/14656566.2015.1013936

16. Strunk T, Doherty D, Richmond P, Simmer K, Charles A, Levy O, et al. Reduced levels of antimicrobial proteins and peptides in human cord blood plasma. Arch Dis Child Fetal Neonatal Ed (2009) 94:F230-1. doi:10.1136/ adc. 2008.143438

17. Misawa Y, Baba A, Ito S, Tanaka M, Shiohara M. Vitamin D(3) induces expression of human cathelicidin antimicrobial peptide 18 in newborns. Int J Hematol (2009) 90:561-70. doi:10.1007/s12185-009-0452-9

18. Murakami M, Dorschner RA, Stern LJ, Lin KH, Gallo RL. Expression and secretion of cathelicidin antimicrobial peptides in murine mammary glands and human milk. Pediatr Res (2005) 57:10-5. doi:10.1203/01. PDR.0000148068.32201.50

19. Trend S, Strunk T, Hibbert J, Kok CH, Zhang G, Doherty DA, et al. Antimicrobial protein and peptide concentrations and activity in human breast milk consumed by preterm infants at risk of late-onset neonatal sepsis. PLoS One (2015) 10:e0117038. doi:10.1371/journal.pone.0117038

20. Kai-Larsen Y, Bergsson G, Gudmundsson GH, Printz G, Jörnvall H, Marchini G, et al. Antimicrobial components of the neonatal gut affected upon colonization. Pediatr Res (2007) 61:530-6. doi:10.1203/pdr.0b013e318045be83

21. Schaller-Bals S, Schulze A, Bals R. Increased levels of antimicrobial peptides in tracheal aspirates of newborn infants during infection. Am J Respir Crit Care Med (2002) 165:992-5. doi:10.1164/ajrccm.165.7.200110-020

22. Marchini G, Lindow S, Brismar H, Ståbi B, Berggren V, Ulfgren A-K, et al. The newborn infant is protected by an innate antimicrobial barrier: peptide antibiotics are present in the skin and vernix caseosa. Br J Dermatol (2002) 147:1127-34. doi:10.1046/j.1365-2133.2002.05014.x

23. Dorschner RA, Lin KH, Murakami M, Gallo RL. Neonatal skin in mice and humans expresses increased levels of antimicrobial peptides: innate immunity during development of the adaptive response. Pediatr Res (2003) 53:566-72. doi:10.1203/01.PDR.0000057205.64451.B7
24. Yoshio H, Tollin M, Gudmundsson GH, Lagercrantz H, Jörnvall H, Marchini $\mathrm{G}$, et al. Antimicrobial polypeptides of human vernix caseosa and amniotic fluid: implications for newborn innate defense. Pediatr Res (2003) 53:211-6. doi:10.1203/01.PDR.0000047471.47777.B0

25. Faust K, Göpel W, Moser K, Temole G, Bartels M, Wieg C, et al. Differential expression of antimicrobial polypeptides in cord blood samples of preterm and term infants. Acta Paediatr (2014) 103:e143-7. doi:10.1111/apa.12544

26. Akinbi HT, Narendran V, Pass AK, Markart P, Hoath SB. Host defense proteins in vernix caseosa and amniotic fluid. Am J Obstet Gynecol (2004) 191:2090-6. doi:10.1016/j.ajog.2004.05.002

27. Olbrich P, Pavón A, Rosso ML, Molinos A, de Felipe B, Sanchez B, et al. Association of human beta-defensin-2 serum levels and sepsis in preterm neonates*. Pediatr Crit Care Med (2013) 14:796-800. doi:10.1097/ PCC.0b013e3182975e0f

28. Campeotto F, Baldassarre M, Laforgia N, Viallon V, Kalach N, Amati L, et al. Fecal expression of human $\beta$-defensin-2 following birth. Neonatology (2010) 98:365-9. doi:10.1159/000315872

29. Jenke ACW, Zilbauer M, Postberg J, Wirth S. Human $\beta$-defensin 2 expression in ELBW infants with severe necrotizing enterocolitis. Pediatr Res (2012) 72:513-20. doi:10.1038/pr.2012.110

30. Starner TD, Agerberth B, Gudmundsson GH, McCray PB. Expression and activity of beta-defensins and LL-37 in the developing human lung. J Immunol (2005) 174:1608-15. doi:10.4049/jimmunol.174.3.1608

31. Levy O, Martin S, Eichenwald E, Ganz T, Valore E, Carroll SF, et al. Impaired innate immunity in the newborn: newborn neutrophils are deficient in bactericidal/permeability-increasing protein. Pediatrics (1999) 104:1327-33. doi:10.1542/peds.104.6.1327

32. Nupponen I, Turunen R, Nevalainen T, Peuravuori H, Pohjavuori M, Repo H, et al. Extracellular release of bactericidal/permeability-increasing protein in newborn infants. Pediatr Res (2002) 51:670-4. doi:10.1203/ 00006450-200206000-00002

33. Nathe KE, Parad R, Van Marter LJ, Lund CA, Suter EE, Hernandez-diaz S, et al. Endotoxin-directed innate immunity in tracheal aspirates of mechanically ventilated human neonates. Pediatr Res (2009) 66:191-6. doi:10.1203/ PDR.0b013e3181aa33d7

34. Walker VP, Akinbi HT, Meinzen-Derr J, Narendran V, Visscher M, Hoath SB. Host defense proteins on the surface of neonatal skin: implications for innate immunity. J Pediatr (2008) 152:777-81. doi:10.1016/j.jpeds.2007.11.030

35. Huttner KM, Bevins CL. Antimicrobial peptides as mediators of epithelial host defense.PediatrRes(1999)45:785-94.doi:10.1203/00006450-199906000-00001

36. Selsted ME. A pocket guide to explorations of the defensin field. Curr Pharm Des (2007) 13:3061-4. doi:10.2174/138161207782110363

37. Salzman NH, Ghosh D, Huttner KM, Paterson Y, Bevins CL. Protection against enteric salmonellosis in transgenic mice expressing a human intestinal defensin. Nature (2003) 422:522-6. doi:10.1038/nature01520

38. Lehrer RI, Ganz T. Cathelicidins: a family of endogenous antimicrobial peptides. Curr Opin Hematol (2002) 9:18-22. doi:10.1097/00062752-200201000-00004

39. Bals R, Wilson JM. Cathelicidins - a family of multifunctional antimicrobial peptides. Cell Mol Life Sci (2003) 60:711-20. doi:10.1007/s00018-003-2186-9

40. Bellm L, Lehrer RI, Ganz T. Protegrins: new antibiotics of mammalian origin. Expert Opin Investig Drugs (2000) 9:1731-42. doi:10.1517/13543784.9.8.1731

41. Levy O, Sisson RB, Kenyon J, Eichenwald E, Macone AB, Goldmann D. Enhancement of neonatal innate defense: effects of adding an N-terminal recombinant fragment of bactericidal/permeability-increasing protein on growth and tumor necrosis factor-inducing activity of gram-negative bacteria tested in neonatal cord blood ex vivo. Infect Immun (2000) 68:5120-5. doi:10.1128/IAI.68.9.5120-5125.2000

42. Levin M, Quint PA, Goldstein B, Barton P, Bradley JS, Shemie SD, et al. Recombinant bactericidal/permeability-increasing protein (rBPI21) as adjunctive treatment for children with severe meningococcal sepsis: a randomised trial. rBPI21 meningococcal sepsis study group. Lancet (2000) 356:961-7. doi:10.1016/S0140-6736(00)02712-4

43. Pergialiotis V, Konstantopoulos P, Karampetsou N, Koutaki D, Gkioka E, Perrea DN, et al. Calprotectin levels in necrotizing enterocolitis: a systematic review of the literature. Inflamm Res (2016). doi:10.1007/s00011016-0963-9

44. Baker EN, Baker HM. Molecular structure, binding properties and dynamics of lactoferrin. Cell Mol Life Sci (2005) 62:2531-9. doi:10.1007/s00018-005-5368-9 
45. Vogel HJ. Lactoferrin, a bird's eye view. Biochem Cell Biol (2012) 90:233-44. doi:10.1139/o2012-016

46. Yang D, Biragyn A, Hoover DM, Lubkowski J, Oppenheim JJ. Multiple roles of antimicrobial defensins, cathelicidins, and eosinophil-derived neurotoxin in host defense. Annu Rev Immunol (2004) 22:181-215. doi:10.1146/annurev. immunol.22.012703.104603

47. Ganz T. The role of antimicrobial peptides in innate immunity. Integr Comp Biol (2003) 43:300-4. doi:10.1093/icb/43.2.300

48. Canny G, Levy O, Furuta GT, Narravula-Alipati S, Sisson RB, Serhan CN, et al. Lipid mediator-induced expression of bactericidal/permeability-increasing protein (BPI) in human mucosal epithelia. Proc Natl Acad Sci U S A (2002) 99:3902-7. doi:10.1073/pnas.052533799

49. Xie Z, Feng J, Yang W, Xiang F, Yang F, Zhao Y, et al. Human $\alpha$-defensins are immune-related Kv1.3 channel inhibitors: new support for their roles in adaptive immunity. FASEB J (2015) 29(10):4324-33. doi:10.1096/f.15-274787

50. Brinkmann V, Reichard U, Goosmann C, Fauler B, Uhlemann Y, Weiss DS, et al. Neutrophil extracellular traps kill bacteria. Science (2004) 303:1532-5. doi:10.1126/science. 1092385

51. Chu H, Pazgier M, Jung G, Nuccio S-P, Castillo PA, de Jong MF, et al. Human $\alpha$-defensin 6 promotes mucosal innate immunity through self-assembled peptide nanonets. Science (2012) 337:477-81. doi:10.1126/science.1218831

52. Arias CA, Murray BE. Antibiotic-resistant bugs in the 21st century - a clinical super-challenge. N Engl J Med (2009) 360:439-43. doi:10.1056/ NEJMp0804651

53. Flamm RK, Rhomberg PR, Simpson KM, Farrell DJ, Sader HS, Jones RN. In vitro spectrum of pexiganan activity when tested against pathogens from diabetic foot infections and with selected resistance mechanisms. Antimicrob Agents Chemother (2015) 59:1751-4. doi:10.1128/AAC.04773-14

54. Haug BE, Strøm MB, Svendsen JSM. The medicinal chemistry of short lactoferricin-based antibacterial peptides. Curr Med Chem (2007) 14:1-18. doi:10.2174/092986707779313435

55. Vincent JL, Marshall JC, Dellinger RP, Simonson SG, Guntupalli K, Levy MM, et al. Talactoferrin in severe sepsis: results from the phase II/III oral talactoferrin in severe sepsis trial. Crit Care Med (2015) 43:1832-8. doi:10.1097/ CCM.0000000000001090

56. Fox JL. Antimicrobial peptides stage a comeback. Nat Biotechnol (2013) 31:379-82. doi:10.1038/nbt.2572

57. Conlon JM, Mechkarska M. Host-defense peptides with therapeutic potential from skin secretions of frogs from the family pipidae. Pharmaceuticals (Basel) (2014) 7:58-77. doi:10.3390/ph7010058

58. Blackburn RM, Verlander NQ, Heath PT, Muller-Pebody B. The changing antibiotic susceptibility of bloodstream infections in the first month of life: informing antibiotic policies for early- and late-onset neonatal sepsis. Epidemiol Infect (2014) 142:803-11. doi:10.1017/S0950268813001520

59. Nelson A, Hultenby K, Hell E, Riedel HM, Brismar H, Flock J-I, et al. Staphylococcus epidermidis isolated from newborn infants express pilus-like structures and are inhibited by the cathelicidin-derived antimicrobial peptide LL37. Pediatr Res (2009) 66:174-8. doi:10.1203/PDR.0b013e3181a9d80c

60. Rogan MP, Geraghty P, Greene CM, O’Neill SJ, Taggart CC, McElvaney NG. Antimicrobial proteins and polypeptides in pulmonary innate defence. Respir Res (2006) 7:29. doi:10.1186/1465-9921-7-29

61. Scharf S, Zahlten J, Szymanski K, Hippenstiel S, Suttorp N, N'Guessan PD. Streptococcus pneumoniae induces human $\beta$-defensin- 2 and -3 in human lung epithelium. Exp Lung Res (2012) 38:100-10. doi:10.3109/01902148. 2011.652802

62. Tang Z, Xu L, Shi B, Deng H, Lai X, Liu J, et al. Oral administration of synthetic porcine beta-defensin-2 improves growth performance and cecal microbial flora and down-regulates the expression of intestinal toll-like receptor-4 and inflammatory cytokines in weaned piglets challenged with enterotoxigenic Escherichia coli. Anim Sci J (2015). doi:10.1111/asj.12540

63. Salzman NH, Hung K, Haribhai D, Chu H, Karlsson-Sjöberg J, Amir E, et al. Enteric defensins are essential regulators of intestinal microbial ecology. Nat Immunol (2010) 11:76-83. doi:10.1038/ni.1825

64. Ménard S, Förster V, Lotz M, Gütle D, Duerr CU, Gallo RL, et al. Developmental switch of intestinal antimicrobial peptide expression. JExp Med (2008) 205:183-93. doi:10.1084/jem.20071022

65. Salzman NH, Polin RA, Harris MC, Ruchelli E, Hebra A, Zirin-Butler S, et al. Enteric defensin expression in necrotizing enterocolitis. Pediatr Res (1998) 44:20-6. doi:10.1203/00006450-199807000-00003
66. Neu J, Walker WA. Necrotizing enterocolitis. N Engl J Med (2011) 364:255-64. doi:10.1056/NEJMra1005408

67. Salzman NH, Underwood MA, Bevins CL. Paneth cells, defensins, and the commensal microbiota: a hypothesis on intimate interplay at the intestinal mucosa. Semin Immunol (2007) 19:70-83. doi:10.1016/j.smim. 2007.04.002

68. Ronayne de Ferrer PA, Baroni A, Sambucetti ME, López NE, Ceriani Cernadas JM. Lactoferrin levels in term and preterm milk. J Am Coll Nutr (2000) 19:370-3. doi:10.1080/07315724.2000.10718933

69. Minami J, Odamaki T, Hashikura N, Abe F, Xiao JZ. Lysozyme in breast milk is a selection factor for bifidobacterial colonisation in the infant intestine. Benef Microbes (2015) 7(1):53-60. doi:10.3920/BM2015.0041

70. Baricelli J, Rocafull MA, Vázquez D, Bastidas B, Báez-Ramirez E, Thomas LE. $\beta$-defensin-2 in breast milk displays a broad antimicrobial activity against pathogenic bacteria. J Pediatr (Rio J) (2015) 91:36-43. doi:10.1016/j.jped. 2014.05.006

71. Sherman MP. Lactoferrin and necrotizing enterocolitis. Clin Perinatol (2013) 40:79-91. doi:10.1016/j.clp.2012.12.006

72. Murata M, Wakabayashi H, Yamauchi K, Abe F. Identification of milk proteins enhancing the antimicrobial activity of lactoferrin and lactoferricin. J Dairy Sci (2013) 96:4891-8. doi:10.3168/jds.2013-6612

73. Froy O. Regulation of mammalian defensin expression by toll-like receptor-dependent and independent signalling pathways. Cell Microbiol (2005) 7:1387-97. doi:10.1111/j.1462-5822.2005.00590.x

74. Liu PT, Stenger S, Li H, Wenzel L, Tan BH, Krutzik SR, et al. Toll-like receptor triggering of a vitamin D-mediated human antimicrobial response. Science (2006) 311:1770-3. doi:10.1126/science.1123933

75. Biron CA. More things in heaven and earth: defining innate and adaptive immunity. Nat Immunol (2010) 11:1080-2. doi:10.1038/ni1210-1080

76. Mandic Havelka A, Yektaei-Karin E, Hultenby K, Sørensen OE, Lundahl J, Berggren V, et al. Maternal plasma level of antimicrobial peptide LL37 is a major determinant factor of neonatal plasma LL37 level. Acta Paediatr (2010) 99:836-41. doi:10.1111/j.1651-2227.2010.01726.x

77. Singh VV, Chauhan SK, Rai R, Kumar A, Singh SM, Rai G. Decreased pattern recognition receptor signaling, interferon-signature, and bactericidal/permeability-increasing protein gene expression in cord blood of term low birth weight human newborns. PLoS One (2013) 8:e62845. doi:10.1371/journal. pone. 0062845

78. Yost CC, Cody MJ, Harris ES, Thornton NL, McInturff AM, Martinez ML, et al. Impaired neutrophil extracellular trap (NET) formation: a novel innate immune deficiency of human neonates. Blood (2009) 113:6419-27. doi:10.1182/blood-2008-07-171629

79. Camacho-Gonzalez A, Spearman PW, Stoll BJ. Neonatal infectious diseases: evaluation of neonatal sepsis. Pediatr Clin North Am (2013) 60:367-89. doi:10.1016/j.pcl.2012.12.003

80. Vergnano S, Sharland M, Kazembe P, Mwansambo C, Heath PT. Neonatal sepsis: an international perspective. Arch Dis Child Fetal Neonatal Ed (2005) 90:F220-4. doi:10.1136/adc.2002.022863

81. Barbeiro DF, Barbeiro HV, Zampieri FG, César Machado MC, Torggler Filho F, Gomes Cunha DM, et al. Cathelicidin LL-37 bloodstream surveillance is down regulated during septic shock. Microbes Infect (2013) 15:342-6. doi:10.1016/j. micinf.2013.01.001

82. Guntupalli K, Dean N, Morris PE, Bandi V, Margolis B, Rivers E, et al. A phase 2 randomized, double-blind, placebo-controlled study of the safety and efficacy of talactoferrin in patients with severe sepsis. Crit Care Med (2013) 41:706-16. doi:10.1097/CCM.0b013e3182741551

83. Velden WJFMVD, van Iersel TMP, Blijlevens NMA, Donnelly JP. Safety and tolerability of the antimicrobial peptide human lactoferrin 1-11 (hLF1-11). BMC Med (2009) 7:44. doi:10.1186/1741-7015-7-44

84. Manzoni P, Rinaldi M, Cattani S, Pugni L, Romeo MG, Messner H, et al. Bovine lactoferrin supplementation for prevention of late-onset sepsis in very low-birth-weight neonates: a randomized trial. JAMA (2009) 302:1421-8. doi:10.1001/jama.2009.1403

85. Manzoni P, Stolfi I, Messner H, Cattani S, Laforgia N, Romeo MG, et al. Bovine lactoferrin prevents invasive fungal infections in very low birth weight infants: a randomized controlled trial. Pediatrics (2012) 129:116-23. doi:10.1542/ peds.2011-0279

86. Manzoni P, Meyer M, Stolfi I, Rinaldi M, Cattani S, Pugni L, et al. Bovine lactoferrin supplementation for prevention of necrotizing enterocolitis in 
very-low-birth-weight neonates: a randomized clinical trial. Early Hum Dev (2014) 90(Suppl 1):S60-5. doi:10.1016/S0378-3782(14)70020-9

87. Akin IM, Atasay B, Dogu F, Okulu E, Arsan S, Karatas HD, et al. Oral lactoferrin to prevent nosocomial sepsis and necrotizing enterocolitis of premature neonates and effect on T-regulatory cells. Am J Perinatol (2014) 31:1111-20. doi:10.1055/s-0034-1371704

88. Ochoa TJ, Zegarra J, Cam L, Llanos R, Pezo A, Cruz K, et al. Randomized controlled trial of lactoferrin for prevention of sepsis in peruvian neonates less than 2500 g. Pediatr Infect Dis J (2015) 34:571-6. doi:10.1097/ INF.0000000000000593

89. Giroir BP, Scannon PJ, Levin M. Bactericidal/permeability-increasing protein - lessons learned from the phase III, randomized, clinical trial of rBPI21 for adjunctive treatment of children with severe meningococcemia. Crit Care Med (2001) 29:S130-5. doi:10.1097/00003246-200107001-00039

90. Guinan EC, Barbon CM, Kalish LA, Parmar K, Kutok J, Mancuso CJ, et al. Bactericidal/permeability-increasing protein (rBPI21) and fluoroquinolone mitigate radiation-induced bone marrow aplasia and death. Sci Transl Med (2011) 3:110ra118. doi:10.1126/scitranslmed.3003126

91. Evans SE, Tuvim MJ, Fox CJ, Sachdev N, Gibiansky L, Dickey BF. Inhaled innate immune ligands to prevent pneumonia. Br JPharmacol (2011) 163:195-206. doi:10.1111/j.1476-5381.2011.01237.x

92. Perron GG, Zasloff M, Bell G. Experimental evolution of resistance to an antimicrobial peptide. Proc Biol Sci (2006) 273:251-6. doi:10.1098/rspb.2005.3301

93. Cantey JB, Milstone AM. Bloodstream infections: epidemiology and resistance. Clin Perinatol (2015) 42:1-16-vii. doi:10.1016/j.clp.2014.10.002

94. Desbois AP, Lang S, Gemmell CG, Coote PJ. Surface disinfection properties of the combination of an antimicrobial peptide, ranalexin, with an endopeptidase, lysostaphin, against methicillin-resistant Staphylococcus aureus (MRSA). J Appl Microbiol (2010) 108:723-30. doi:10.1111/j.1365-2672. 2009.04472.x

95. Jindal HM, Le C-F, Mohd Yusof MY, Velayuthan RD, Lee VS, Zain SM, et al. Antimicrobial activity of novel synthetic peptides derived from indolicidin and ranalexin against Streptococcus pneumoniae. PLoS One (2015) 10:e0128532. doi:10.1371/journal.pone. 0128532

96. Dosler S, Mataraci E. In vitro pharmacokinetics of antimicrobial cationic peptides alone and in combination with antibiotics against methicillin resistant Staphylococcus aureus biofilms. Peptides (2013) 49:53-8. doi:10.1016/j. peptides.2013.08.008

97. Le C-F, Yusof MYM, Hassan MAA, Lee VS, Isa DM, Sekaran SD. In vivo efficacy and molecular docking of designed peptide that exhibits potent antipneumococcal activity and synergises in combination with penicillin. $S c i$ Rep (2015) 5:11886. doi:10.1038/srep11886

Conflict of Interest Statement: The authors declare that the research was conducted in the absence of any commercial or financial relationships that could be construed as a potential conflict of interest.

Copyright (๑) 2016 Battersby, Khara, Wright, Levy and Kampmann. This is an open-access article distributed under the terms of the Creative Commons Attribution License (CC BY). The use, distribution or reproduction in other forums is permitted, provided the original author(s) or licensor are credited and that the original publication in this journal is cited, in accordance with accepted academic practice. No use, distribution or reproduction is permitted which does not comply with these terms. 